\title{
ONE CANNOT KNOW ANATOMY TOO WELL: JËKABS PRĪMANIS AND ANATOMY FOR ARTISTS
}

\author{
ULDis ZARIN̦Š ${ }^{1}$, IEVA LĪBIETE ${ }^{2}$ \\ ${ }^{1}$ The Art Academy of Latvia, Rīga, Latvia \\ ${ }^{2}$ Institute of History of Medicine, Rìga Stradiņš University, Rīga, Latvia
}

\begin{abstract}
In recent years the scholars have stressed the role of anatomical collections and their histories as crucial to new interdisciplinary studies that investigate the interaction between arts and sciences. This could be attributed as well to the new exposition of Anatomy museum of Riga Stradinš University, that was opened to visitors in 2021. Museum galleries reveal the interplay between anatomists, artists and museum specialists, both in historical and contemporary contexts. Between the specimen jars and human bones, the anatomical drawings of both medical and art students are displayed. Sculpture-like life casts of congenital deformities made by anatomists contrast the ideal but skinless muscle man L'Ecorche Combattant. Historical artefacts interact with modern anatomical 3D illustration and multimedial solutions created by contemporary artists. No doubt, artists were and are important for visualising, explaining and displaying anatomy. But what about the role of anatomists in arts? This article aims to investigate an episode in the biography of long-time museum director anatomist and anthropologist professor Jēkabs Prīmanis (1892-1971) and his role in teaching the so-called plastic anatomy to the students of the Art Academy of Latvia.
\end{abstract}

Keywords: plastic anatomy; anatomy for artists; medical art; Jēkabs Prīmanis; Art Academy of Latvia; University of Latvia

\section{INTRODUCTION}

The establishment of the Anatomy Museum is closely tied to the beginnings of higher medical education in Latvia. The Museum was founded by the Head of the Institute of Anatomy of the Faculty of Medicine of the Higher School 
of Latvia (from 1924 - University of Latvia), Swedish anatomist and anthropologist Gaston Backman (1883-1964). In 1920, the former Riga Orthodox Seminar building at Kronvalda (then Puškina) bulvāris 9 was allocated for the establishment of the Faculty of Medicine, including Anatomy Institute and Museum. Since then, this architecturally peculiar building has been known as the Anatomicum.

Following Backman's directions, the student study premises - an amphitheatre auditorium for lectures and a dissecting room for practical assignments were established on the second floor of the building. Offices of the institute staff, a laboratory for creating moulages, a drawing space, and a photography space, as well as a separate osteology space were established on the second floor, too. In the basement, the so-called corpse cellar was created, but in the very centre of the building, as an integral part of the Institute of Anatomy - the Anatomy Museum [22: 55,56]. For this purpose, Backman allocated the most luxurious part of the building: the former chapel of the Greek Orthodox Seminary, which was a majestic room, creating transcendent feelings. The Anatomy Museum was there until 2017, when it was decided to move it to the renovated modern museum building nearby, in the territory of the Anatomicum. However, already for 100 years the medical students have been studying Anatomy in the Anatomicum.

Backman did not carry out the installation of the Museum and the Institute of Anatomy alone. Already in May 1920, he was joined by Jēkabs Prīmanis (1892-1971), who had recently finished his studies and had gained experience as a medical officer during the war. Primanis had studied medicine from 1911 to 1913 in the University of Tartu (then Yuryev). Afterwards, presumably due to financial reasons, he continued his studies in the St. Petersburg Military Medical Academy. Primanis finished his studies in 1918, after the 1st World War. Having returned to Latvia, he applied for work at the newly established Higher School of Latvia, became a student and companion of Backman, and, later, the first Latvian professor of Anatomy and Anthropology. Prīmanis was the Head of the Institute of Anatomy and the Anatomy Museum from 1929 until his emigration in 1944. He spent the second part of his life in the USA, becoming a popular Anatomy professor at the University of Pittsburgh [14: 16-33, 64-67].

Prīmanis' biography and scientific activities, especially in the field of Anthropology, have been most widely studied by Rita Grāvere. In 2017, a monograph dedicated to Prìmanis was published under the title So we return... [14]. Of all Prīmanis' contemporaries, his assistant, later a neurosurgeon, Kārlis Arājs (1915-2005) published the most extensive memoirs in the book Latvian 
Bones: Memories About the Anatomicum and the Thrive of Anthropology in Latvia [3]. Undoubtedly, Primanis was one of the patriarchs of Latvian medical education. A less known fact is that he also played an important role not only in medical education, but also in the development of art education in Latvia, as the first and only professor of Plastic Anatomy at the Art Academy of Latvia during the interwar period. This aspect of Primanis' professional activity 'falls between' disciplines and is often overlooked, which is the reason why neither the medical nor the art historians have attempted to research the matter.

Primanis himself did not keep a diary and has left few memories. Yet, even in his short biographies he always mentioned the fact of being a Professor of Anatomy at the Art Academy of Latvia. It is understandable, because he was in work relations with this Latvian higher education institution for almost as long as with the University of Latvia. Already in 1922, having worked as an assistant and a prosector at the Institute of Anatomy, Primmanis received an invitation from the newly founded Art Academy of Latvia to teach Plastic Anatomy [11]. Thus began the collaboration between Primanis and the Art Academy of Latvia which lasted for 22 years, and, figuratively speaking, Jēkabs Prìmanis has been standing at the cradle not only of the Faculty of Medicine of the University of Latvia, but also of the Art Academy of Latvia.

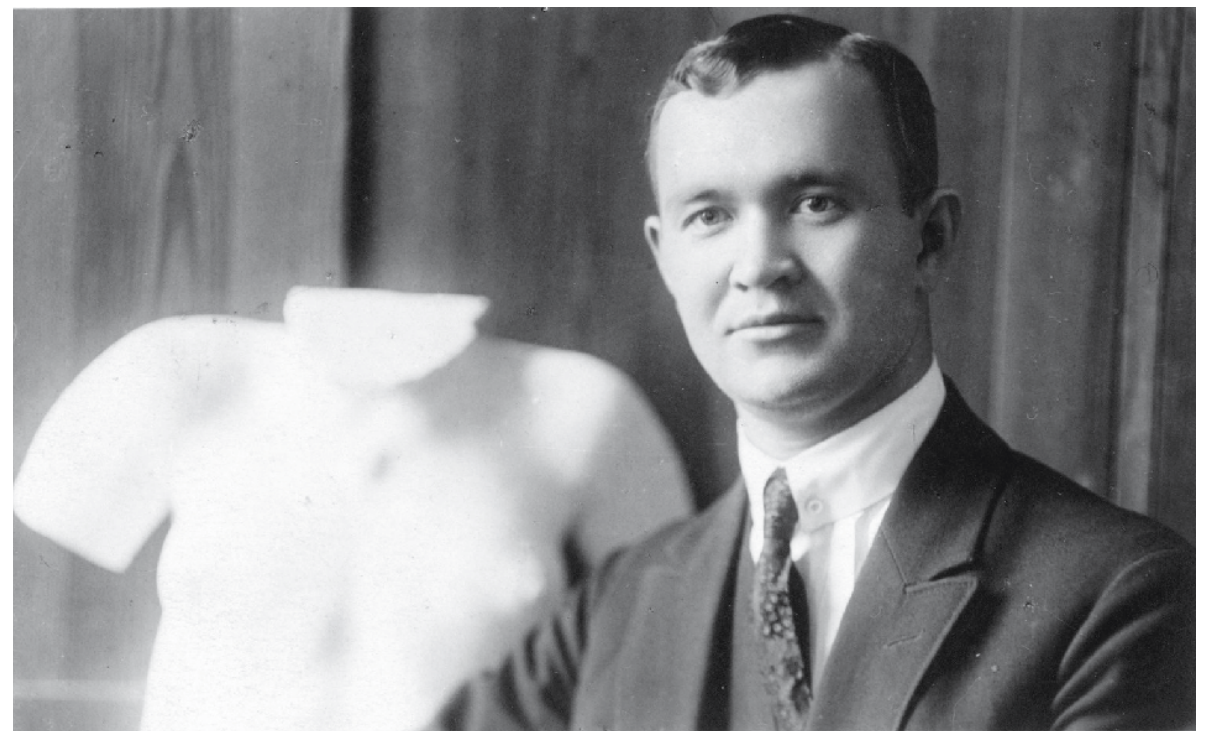

Figure 1. Jēkabs Prīmanis in 1920s. (Pauls Stradiņš Museum of History of Medicine). 


\section{THE BEGINNINGS OF THE ART ACADEMY OF LATVIA AND INTRODUCTION OF PLASTIC ANATOMY}

At the beginning of the 20th century the educated artists of Riga art circles most often had studied in St. Petersburg, either at the Imperial Academy of Arts founded in 1757 or at the School of Technical Drawing founded by Alexander von Stieglitz in 1876. After World War I, with the establishment of the Latvian State, it became possible to carry through the idea that had been nurtured already in the pre-war years: opening a national higher education institution for art in Riga. So, on 20 August 1919 the Cabinet of Ministers of the Provisional Government of Latvia made a decision to found the Art Academy of Latvia. The famous Latvian painter Vilhelms Purvitis (1872-1945) was appointed to the position of its first director, and later he was elected the rector [28: 397-398].

Vilhelms Purvitis himself had studied at the St. Petersburg Imperial Academy of Arts from 1890 to 1897, specialising in landscape painting, and before the war he had been the head of the Riga City Art School. Apart from Vilhelms Purvitis, other famous Latvian artists also participated in the establishment of the Art Academy of Latvia, for example, graphic artist Rihards Zariņš (1869-1939), painter and sculptor Jānis Roberts Tillbergs (1880-1971), sculptor Teodors Zaļkalns (1876-1972), set designer and painter Jānis Kuga (1878-1969) - all of them had initially studied at the art schools of St. Petersburg and all of them 'faithful to the art pedagogy principles of the Petersburg Art Academy, reformed in the '90's, the principles in force at the Stieglitz' Art School, as well' [18: 94]. For this reason, it was only natural that the structure of studies at the Art Academy of Latvia was created, following the example of the Art Academy of Saint Petersburg.

Which means that the total planned length for the art studies was six years on average. First, the students had to take general classes in drawing and painting, followed by a study period in master workshops. In parallel with the practical classes, they had to study theoretical or so-called scientific subjects - Art History, Ethnography, Theory of Shading, Perspective, Anatomy, etc., all of them being a substantial part of the academic art education of the 19th-20th centuries [28: 400]. Due to this 'academic' approach taken over from St. Petersburg, Purvitis was criticised for the lack of modernity in the study programme. Artists who saw the future of art in fauvism, cubism, constructivism reproached the Academy for being old-fashioned. As described by art historian Tatjana Kačalova (1915-2010), Purvitis was worried about the spread of 'radical modernist' trends and a potential demise of professional mastery, 
therefore he was conscious that 'the further development of national art needed realism based on the classical tradition. This could only be provided by such an art academy where nature studies were at the core of the study programme [18: 90].' Nature studies included the studies of the human body. The human was still the main subject of the academic art. For this reason Plastic Anatomy was planned as a four-semester course in the study programme of the Art Academy of Latvia.

In October 1921, Art Academy of Latvia started providing education. One of the main tasks in order to begin the educational process was hiring lecturers. But who would be able to teach Plastic Anatomy? A medical doctor? Or maybe an artist? Historically, Anatomy was integrated in the art training. But since the 18th century Anatomy became a separate subject at the art academies and thus increasingly was taken out of the hands of artists and left to official medical man [8: 30]. Newly established Art Academy of Latvia decided to search for a professor among Latvian anatomists.

This medical, scientific approach to Plastic Anatomy was also, supposedly, taken over from the Imperial Academy of Arts. Today it is operating as St. Petersburg State Academic Institute of Painting, Sculpture and Architecture named after I. E. Repin and at the present, Plastic Anatomy is still taught there in depth: besides many historical anatomy preparations, anatomic moulages, and muscle casts, even the horse drawing studio with its stables has been preserved. Traditionally, teaching Plastic Anatomy at the St. Petersburg Academy of Arts has been the field of expertise of medical doctors and anatomists. Plastic Anatomy was introduced to the Academy curriculum in 1831 [34: 91]. The first Plastic Anatomy professor and study programme developer was the famous Russian medical doctor and anatomist, Ilya Vasilyevich Buyalskiy (1789-1866), also the Head of the Anatomy Chair of the St. Petersburg Military Medicine Academy. In the Study programme developed by Buyalskiy, osteology, myology, and angiology were included as far as it could touch surface anatomy and movement, as well as the study of body parts, fat, proportions, and sex differences [34: 86].

All the following Plastic Anatomy professors at St. Petersburg Academy of Arts up to the beginning of the 20th Century also were anatomists. During the period when the future rector of the Latvian Art Academy, Purvitis, was studying at the St. Petersburg Academy of Arts, anatomy was taught to the artists by the Head of the Department of Anatomy at the Saint Petersburg Military Medical Academy Alexander Ivanovich Tareneckiy (1845-1905) [2: 6].

That is why it is no coincidence, that, while recruiting staff for the Art Academy of Latvia, Purvitis specifically turned to the Institute of Anatomy at 
the Faculty of Medicine of the newly founded University of Latvia. And Jekkabs Primanis responded to this invitation, merging the two positions.

\section{ANATOMY IN ART}

On 22 February 1922, Jēkabs Prīmanis was elected external Senior Assistant Professor in Plastic Anatomy at the Art Academy of Latvia [4: 9]. Primanis was 30 years old at the time with two years of experience as an assistant and a prosector at the Institute of Anatomy of the University of Latvia. The task to create a study programme for art students was a lot more difficult for the young anatomist than one might think. Plastic Anatomy was and is an extremely interdisciplinary science, where not only the knowledge of Anatomy is needed, but also a fundamental understanding of artist's work and needs.

For this reason, in the summer of 1922, the Art Academy of Latvia had sent Primanis on a mission to 'German Art universities' [4: 13], so that the young professor could study the methods of teaching Plastic Anatomy. Unfortunately, there is no information upon how the mission went, because Primanis' mission reports have not been preserved in the archive of the Art Academy of Latvia. In the Curriculum, written in 1937, for application for the position of a professor at the Art Academy of Latvia, Primanis pointed out that in 1925-1926 he had resided in the USA and Germany as a Rockefeller Fellowship recipient, primarily studying Anatomy and Histology issues. Yet, in parallel with these studies, Primanis had got acquainted with methods of teaching Plastic Anatomy in the USA, in Chicago and Philadelphia, as well as in Munich, Germany [4: 34]. Unfortunately, there is no more detailed information about that.

Despite the difficult beginning, the study programme was developed and remained formally unaltered during the whole interwar period. As demonstrated in the operational report of the Art Academy of Latvia [28: 400], Anatomy among other scientific subjects was then considered equally important and mandatory. Meaning, one could receive art education in Latvia only by listening to Primanis' lectures and passing the exams in this speciality.

The young artists studied anatomy for two years, four hours a week. At the beginning, the course was named Plastic Anatomy. From the 1930s, it was divided into two parts: General Anatomy in the first year and Plastic Anatomy in the second. The artists started the first course by learning osteology and myology. The artists had lectures at the same place as the medicine students at the Anatomicum, where Primanis was said to have demonstrated human body parts and muscles preserved in formalin [7: 771]. The Anatomicum and 
the Museum of Anatomy with its exhibits remains in the memories of both medical and art students. It is remembered not only as a place for studying the complicated science of Anatomy, but also as a place where students, facing human body parts preserved in formalin, confront with their own mortality. The extraordinary mood in the premises of the Anatomy museum is described by the doctor and publicist Miervaldis Birze (1921-2000), who started studying medicine in 1939: 'At the first glance, the monotonously painted premises with Byzantine arches in the ceilings and hallways seemed unpleasantly cold. Yet, what could one expect from the hybrid of a church and an anatomy museum, which is filled with showcases full of soulless human body parts...[10: 41]' Similarly, artist Leonids Linauts (1914-1998), who entered the Art Academy in 1941, wrote in his memories that the premises and the spacious auditorium filled with formaldehyde vapours made many art student shiver [23: 998]. In turn, artist and famous children's book illustrator Margarita Kovalı levska (19101999), who started her studies in the Art Academy in 1929, thus described her first meeting with a skull: 'There my eyes met for the first time an overly friendly smile of a skull [...] I stepped in doubt. Yet, Primanis calmly turned it in his hands like a globe full of secrets [19]'.

However, another art student was inspired by the mood of the Anatomicum when choosing a topic for his graduation work. In 1932, painter Maksimilians Mitrevics (1901-1989) created his imposing and grandiose painting The Anatomicum, that received the highest honours [13]. The painting shows the complicated atmosphere of the dissection room at the Anatomicum, where a young medicine student is examining a preparation in a vessel next to the dissection table. This painting was bought in 1933 by the Institute of Anatomy, and it is still kept in the Anatomicum today [14: 109].

Besides attending lectures at the Anatomicum, the students had to prepare detailed bone and muscle drawings from the studied material. The students could copy them from Anatomy study tables and Anatomy books [23: 998]. Primanis made the students memorise the names of the bone and muscle structures in Latin, as well. There is evidence about it not only in the memories of the artists [26: 197], but also the lecture notes [6] and detailed Anatomy tables, where the structures are explained in Latin terms, preserved to this day [5]. From the preserved tables, one can conclude that in the first course the static skeletal and support system structures were drawn, and in the second course écorché was drawn in various movements.

The second-year lectures in Plastic Anatomy were delivered in the premises of the Art Academy, where the professor drew the location of muscles and changes in the movement on the flesh of a live model. After these lectures, the 


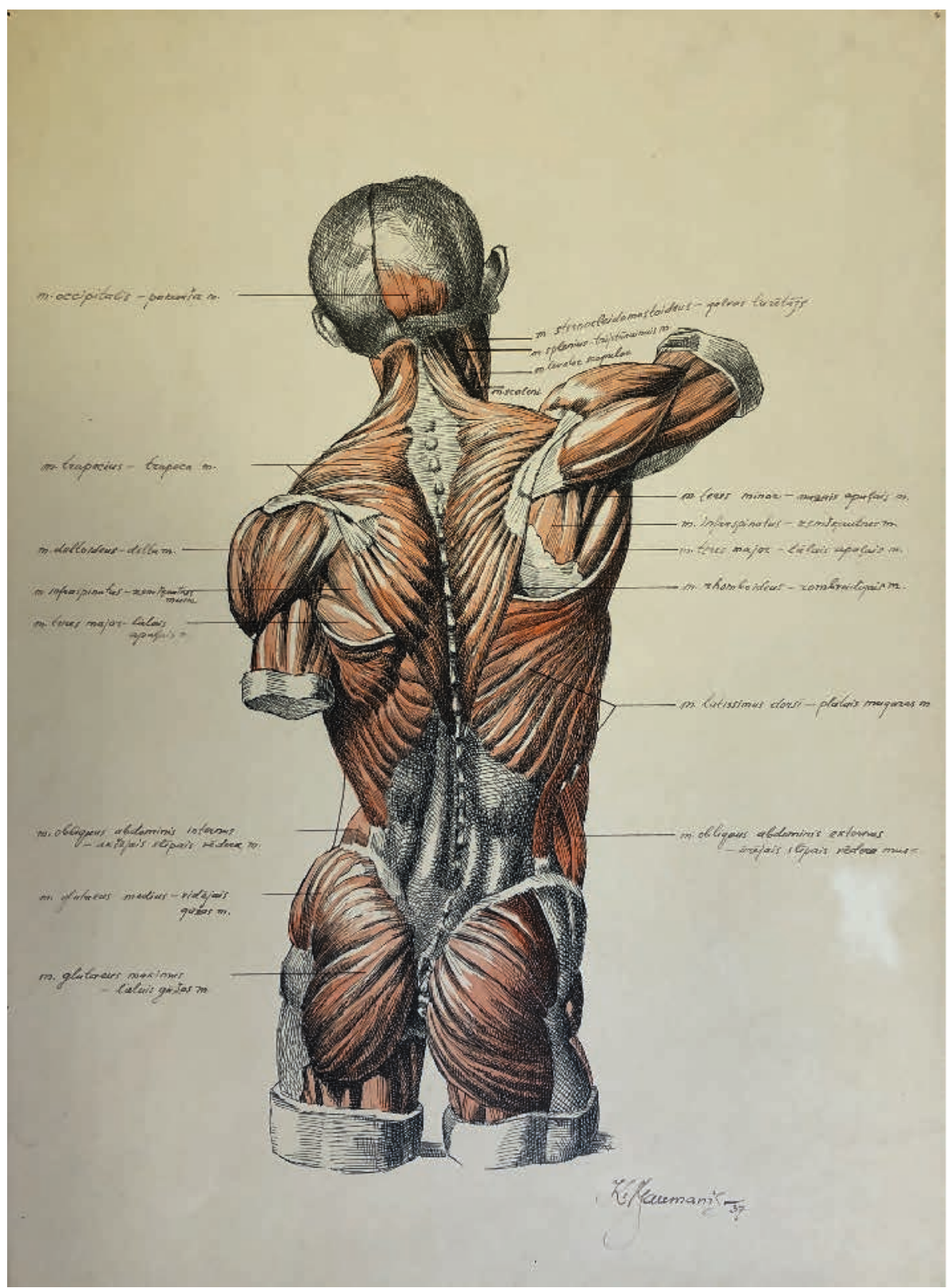

Figure 2. Anatomical drawing by Kārlis Baumanis, 1937. (Pauls Stradiņš Museum of History of Medicine). 
poor model went home painted in blue and red like a masterpiece of Picasso himself', remembers Jānis Audriņš (1898-1994), who studied Anatomy with Primanis in the 1920s [7: 771]. Similar memories about the painting of the model are shared by Margarita Kovalevska. She remembered a scene during a lecture of Anatomy, when an assistant of Primanis was standing stark naked in front of the huge audience and 'Mr. Primanis was drawing the shapes of muscles on his flesh, making the guy tense, relax, everything was exactly the same as in the previous lecture about the back muscles. What a relief that the lecture ended, and the guy stepped back in his pants again [15: 103]'.

Primanis said that one can never know Anatomy too well [14: 78]. It seems that he related this not only to the medicine students, but to the art students, as well. The exams for arts students were serious, and these exams were considered the most difficult by the students. As painter Kārlis Neilis (1906-1991)

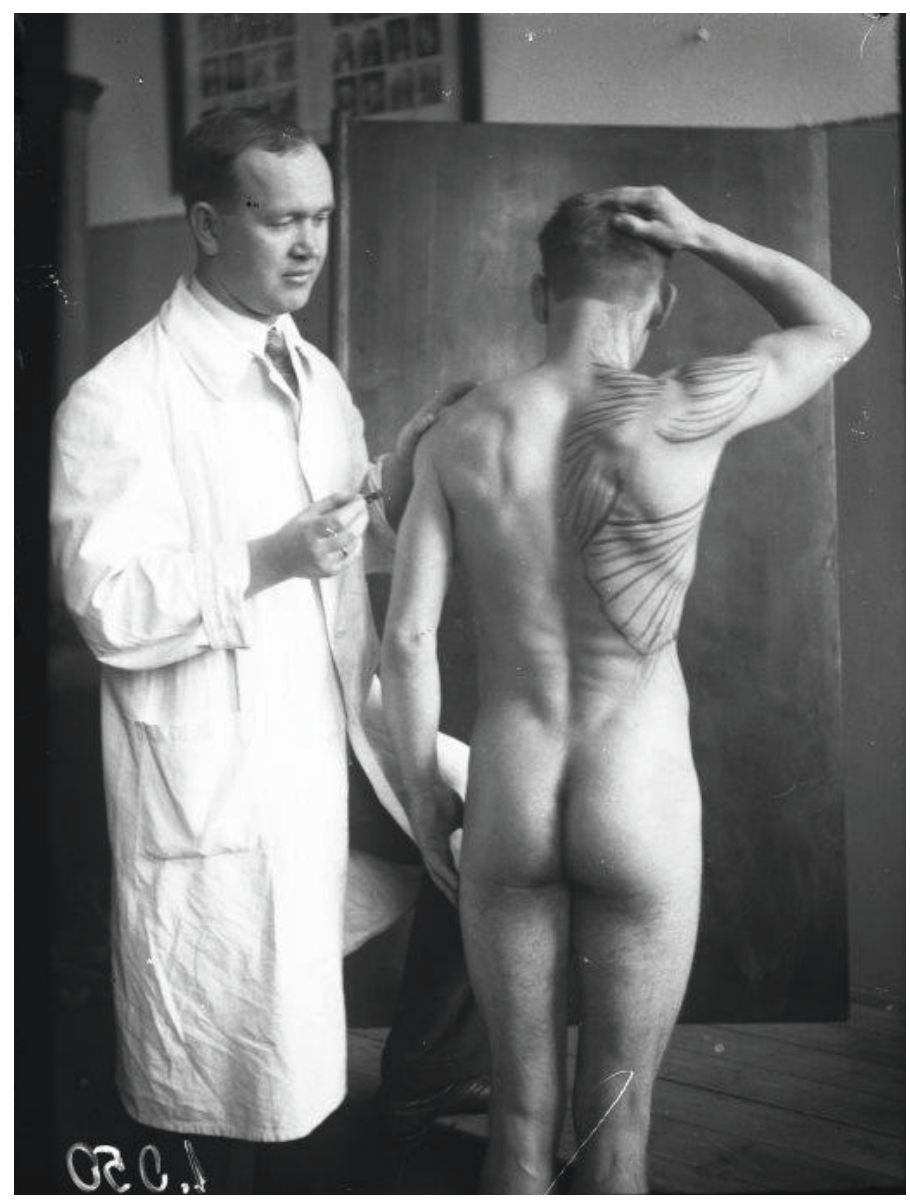

Figure 3. Jēkabs Primanis drawing the location of muscles on a live model, 1930s. (RSU Anatomy museum). 
describes in his memories, "We not only had to know the names of the muscles, but also where they are located, the places where they are attached to the bones, also which movements activate each of them and what shape they take during the movement...[26: 197]' Prìmanis admitted the students to the exams only when they could show careful elaborated tables of Anatomy drawings and exceptional drawings served to pave the road well during the exams [24]. His rigour is remembered by many artists. Those painters, who said they did not need Anatomy, had to come to the exams for years, until Primmanis finally took mercy and gave them a grade of three [14: 107].

After all, Anatomy in the Art Academy of Latvia became an elitist filter of sorts, measuring the exceptional skills of the future artists. Without knowledge in this discipline, the students had no chance to get accepted to the figure painting and sculpture master classes. According to the memories of Leonìds Linauts, who studied at the Academy in the 1940s, if the student had received the top grade in both General Anatomy and Plastic Anatomy, his road to the master workshop of figure painting was paved and the gates were open [24].

\section{ART IN ANATOMY}

The studies of Plastic Anatomy, as one may think, also left an imprint on the way Primanis taught Anatomy to medical students. Often, former medical students in their memoirs used the fact that Primanis taught Anatomy at the Art Academy as an explanation of his drawing skills, perception of space, or preference towards the anatomy of the shape and the surface. He himself collected art and taught the future medical practitioners to love art as well, suggesting they visit exhibitions of the Art Academy students, which they did [10:41].

Undoubtedly, good drawing skills are a fundamental tool in the hands of an Anatomy lecturer. But drawing is not the only important thing. An anatomist has to look at things like an artist and feel the laws of perspective. As Mavrodi et al. well put it in their publication on the interaction of art and anatomy: 'anatomist has to observe, orientate himself even with eyes closed inside the human body and think using the principles of perspective. In other words, he has to face the picture of the body not as a surface but as a space, in order to understand which he must imaginatively walk through the anatomic elements and see what lies behind them [25:274].'

It seems that Primanis had all these qualities. Doctor Miervaldis Birze has pointed out in his memories that Primanis knew how to teach Anatomy spatially: 'He drew schemes with both hands on the blackboard. Drawing with 
the right, then correcting at the same time with the left. There was always chalk in at least three colours. It was not without reason that Primanis taught Plastic Anatomy in the Art Academy [10: 41].' Doctor Viktors Straubs (1918-2016) left similar memories: 'Professor Prīmanis was an exceptional draughtsman [...] Using coloured chalk, he clearly indicated on the blackboard the mutual relations between different shapes and their parts [33: 159].'

Teaching Anatomy in three dimensions manifested not only in the lecture hall on the blackboard, but also in the dissection room. Doctor Kārlis Arājs, former assistant of Primanis, remembered that before starting a dissection together with the medicine students, Primanis used a similar pedagogical method as in the Plastic Anatomy classes for the art students: he drew anatomical orientation lines on the corpse and demonstrated the projection of organs in relation to the surface of the body [35: 66].

It must be mentioned that realising the importance of anatomical drawing in learning Anatomy, artists - anatomy table drawers, whose works unfortunately have only been preserved in the photographic images of those days, continued working in the institute for the entire interwar period.

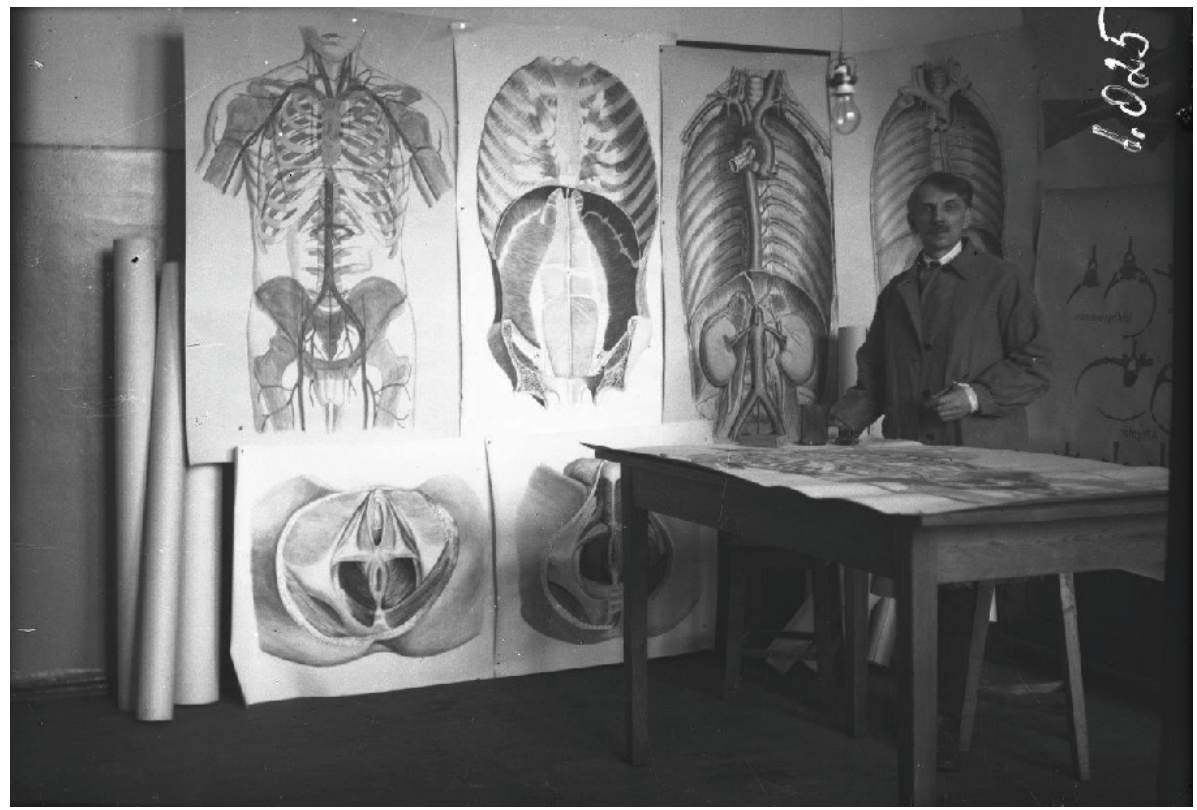

Figure 4. A drawing room at the Institute of Anatomy. 1920s. (RSU Anatomy Museum). 


\section{PRĪMANIS' PLASTIC ANATOMY}

Nowadays, Plastic Anatomy could be defined as a discipline of classic art education that studies the surface shape of a human or animal body and its changes in various functional states in the context of internal anatomical changes and during ontogenesis.

Conventionally, one can distinguish two directions, two parallel paradigms in Plastic Anatomy: the utilitarian and the scientific. The study subject and the departure point in the utilitarian approach is the human shape, which eventually gets anatomically explained. However, in the scientific direction, the departure point is Anatomy and Physiology, and only then its influence on human shape is explained. One might think these are minor differences, yet by changing the focus, different pedagogical results are achieved.

Memories written by artists allow us to make judgements about the Plastic Anatomy course of Primanis only pro forma. Almost the only documentary source allowing us to approximately judge the contents of the course read by Primanis are the lecture notes luckily preserved and kept in the archives of Anatomy Museum. Those were donated to the Anatomy Museum in 1992 by sculptor Kārlis Baumanis (1916-2011), who entered the Art Academy of Latvia in 1936. They consist of five notebooks dated with study years 1936/1937 and 1937/1938 [6]. According to the curriculum, the first three notebooks are

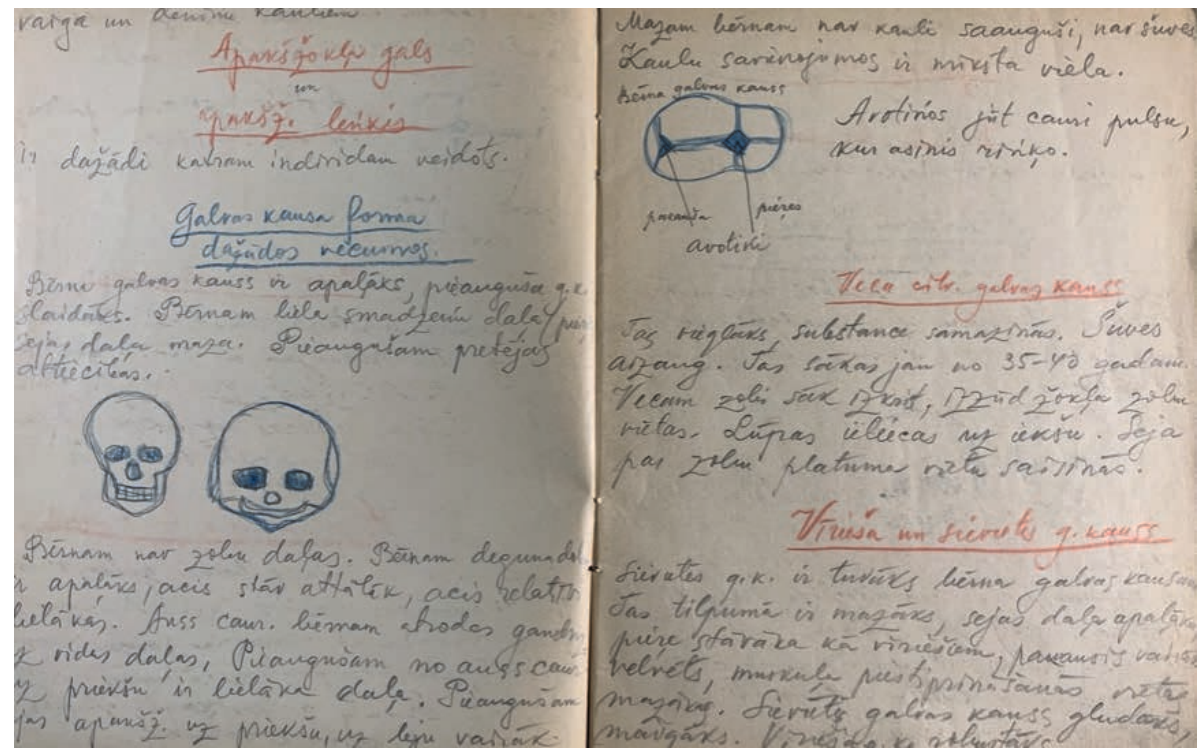

Figure 5. Lecture notes of Kārlis Baumanis, 1936/1937. (RSU Anatomy Museum). 
dedicated to General Anatomy and the last two notebooks are dedicated to Plastic Anatomy. The notes by Baumanis are illustrated with small schematic drawings.

Analysing the preserved lecture notes, it is possible to conclude that, at the end of the 1930s, Jēkabs Prìmanis was somewhere in between both paradigms, but closer to the scientific approach. Mostly, he analysed the anatomic construction of the human being and then discussed the manifestation of anatomy in form, which is understandable, taking in regard his medical education and experience as an anatomist. Yet, by the end of his course, moving from General to Plastic Anatomy, his lectures became more utilitarian. Partly because in the Plastic Anatomy section he addressed anthropological issues more and more.

The General Anatomy programme for the Art Academy students, was different of course, from the medical student programme. Artists were taught hardly anything about the internal organs and their functions, focusing only on osteology and myology. From the lecture notes of Baumanis, we can see that art students were introduced to the structure of skeleton, joints, muscles, their attachment points and functions. The mechanics of the big joints received a more detailed analysis. Sometimes, possibly out of

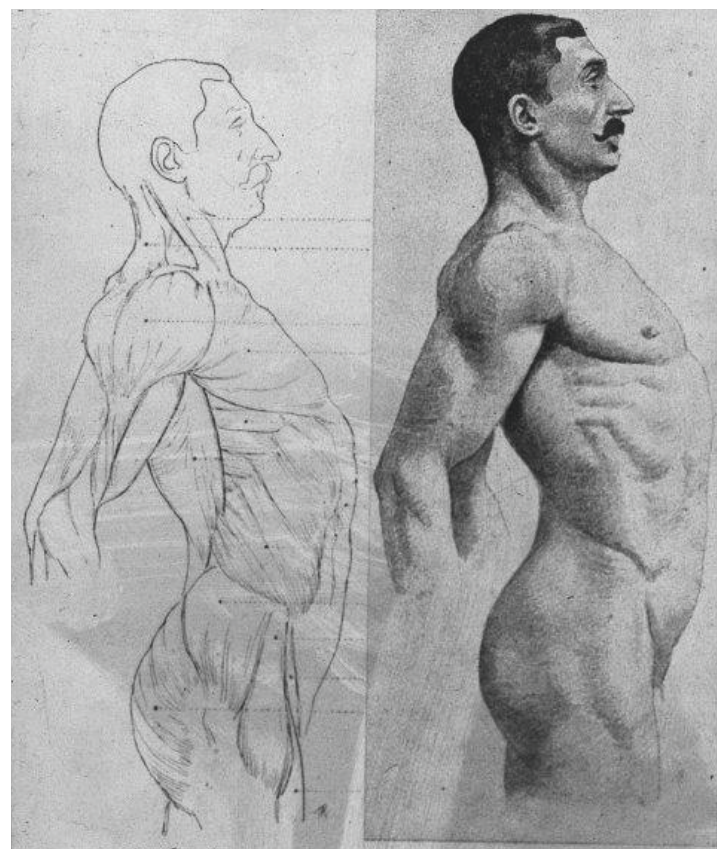

Figure 6. Glass diapositive with a drawing from Richer's Anatomie artistique. (RSU Anatomy museum). habit, Prīmanis discussed in his lectures such structures that have no plastic meaning, for instance, the ethmoid bone, the deeply located musculus quadratus lumborum, or suddenly discussed the internal structure of the eye in detail. Altogether, the General Anatomy section leaves a formal, even dry impression. Only when reaching the topic of the skull did the lectures of Primanis become livelier and his real passion - anthropology started manifesting. Having addressed the skull shape 
differences by age, gender, nation, and race, Prīmanis introduced art students even to cephalic index calculations. It is no surprise, because the first work of Prīmanis himself in anthropology was in craniology [27]. He could talk to students about the skull with great excitement. Artist Margarita Koval?evska also remembers that: 'Pointing at the eye orbits, he told the story of the lakes that had run dry. In these lakes, the shining light was once reflected, all that the vision can perceive. [....] And even the skull alone, where once the brain had been functioning, in his perception was superior to cathedral vaults [19].'

In the second part of the course, Plastic Anatomy, Primanis addressed the topics more relevant for artistic needs: the skin, the body hair, fat, the visible blood vessels, body parts and their changes in movement, differences in age and gender, proportions. Anatomy museum holds diapositives used in the lectures in 1920s and 1930s. Among them glass plates with drawings from famous Anatomie artistique [29] by French author's Paul Richer (1849-1933).

Here, in the Plastic Anatomy course, the passion of Primanis for anthropology is revealed in full - his definition of Plastic Anatomy considerably overlaps with the field of interest of anthropology. 'Plastic Anatomy is the anatomy of outer shapes. You have to compare a man and a woman; signs of age; size and shape of adults and children; relations between the length and the width (the proportions). What is an average, healthy person?', Baumanis wrote.

The literature that was suggested for students, as demonstrated by Baumanis notes, included works more related to anthropology, than to Plastic Anatomy. Among the mentioned works were those of Ernst Wilhelm Brücke (1819-1892) [9], Carl Heinrich Stratz (1858-1924) [32], Hermann Krukenberg (1863-1935) [20] and Karl Langer (1819-1887) [21].

Art students were introduced to typical Latvian characteristics of appearance, shape of the face, differences in hair and eye colour in different regions of Latvia based on Prīmanis' and Backman's research. From the memories of art students, it is known that Primanis liked to share his anthropologist skills of observation, sometimes in a curious way. Artist Linauts remembers that once in a lecture, Primanis addressed a student he did not know, asking if by chance he was not of the descent of Don Cossacks. He based his assumption on the appearance of the student. 'Dark pigmentation of the skin, thin muscles, restless glance, besides some of the facial traits you, student, possess, are very characteristic to the typology of these cavaliers.' Learning that the student has a very local name and surname: Jānis Pauluks, Primanis only noted that this surname is quite widespread in Donbas and calmly continued to deliver the lecture [24]. 
It is known that Primanis was passionate about Anthropology also in the lectures at the Faculty of Medicine. Haralds Voskis (1928-2011), the former Professor of Anatomy at Riga Medicine Institute (now Rìga Stradiňš University), referring to witness stories wrote that among the medicine students of Prìmanis there was a grounded view that the anatomy material should be studied mainly using the then popular Rauber-Kopsch anatomy handbook in

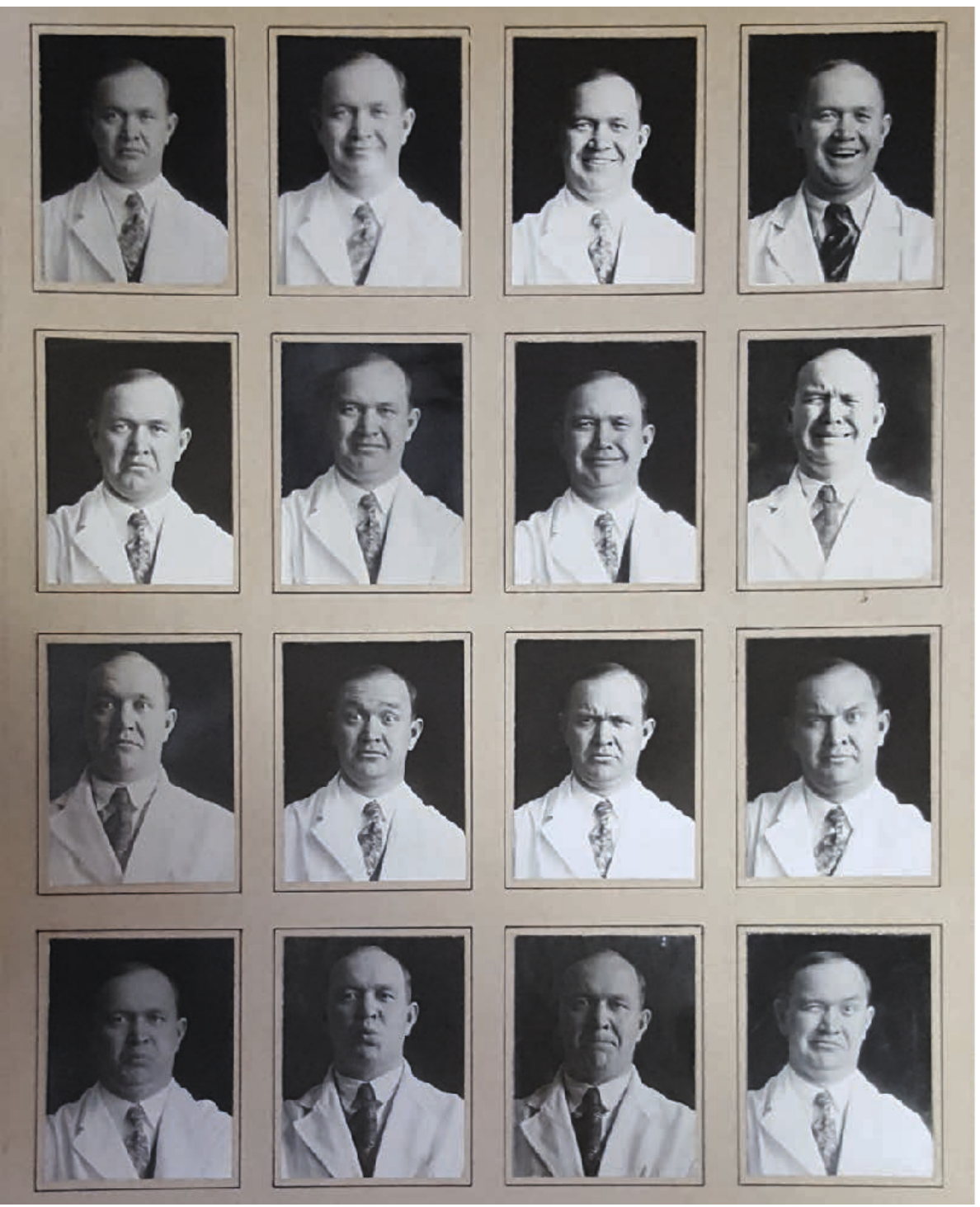

Figure 7. A teaching aid. Jēkabs Prïmanis demonstrates the movements of facial muscles. 1930s. (RSU Anatomy Museum). 
German, because the professor preferred to dwell more upon the anthropological aspects of anatomy [35: 65,66]. If the anthropological aspects could seem less important for medical students, for art students, on the contrary, they seemed very useful because the skill to not only observe differences between different people and groups of people, but also the ability to describe them to be able to portray them later was and is a very important instrument in the creative process.

\section{PRĪMANIS' LEGACY IN ART}

As already mentioned, the Art Academy of Latvia in the beginning of its development was based on the traditions taken over from the St. Petersburg Academy, where the studies of nature and human being, including Anatomy, had an important role. These trends as well as their criticism remained throughout the interwar period. In 1937, painter Uga Skulme (1895-1963), analysing Latvian and Lithuanian Contemporary Art Exhibitions, pointed out that the Latvian Society, contrary to its neighbours, still believes that in art good is 'only the smooth, the polished, similar to nature, descriptive, etc. that died already in the 19th century' [30: 375]. Partially, he blamed the Art Academy for that and the generation of senior artists and professors reigning there. Yet, it was not the only reason. The spirit of the era should also be taken into account. By the end of the 1930s, in a number of authoritarian countries there was a return to classical traditions and its interpretations. National romanticism, passion about the beauty of the human body and physical culture was raised to a national level. Many European countries invested huge resources in studying the roots and characteristics of their nations. Latvia was no exception in this. Even more so, because it had just received a national independence. For this reason, the 1930s were the Golden Age of Latvian ethnogenetic research and physical anthropology, and in art it was the time when figurative painting flourished. Naturally, professor Jēkabs Prīmanis, the coryphaeus of Latvian Anthropology, excellently fit in the mainstream of Latvian Science and Art education, because the fields of interest of the scientific direction of Plastic Anatomy and Physical Anthropology widely overlapped.

Altogether, Jēkabs Primanis worked as an Anatomy professor in the Art Academy for 22 years, having taught Anatomy to more than a thousand art students. Art historian Ingrīda Burāne has stressed the important role of Primanis in the highly appreciated Latvian painting of the 1930s, saying that the development of the entire Latvian realist painting, especially the most impor- 
tant and valuable part of it is connected with the human body and especially the portrait [11]. And, undoubtedly, professor Jēkabs Prìmanis was the one who shaped the understanding of the human body structure in students of the Art Academy of Latvia during the interwar period.

A noteworthy fact is that one of Primanis' students in the Art Academy of Latvia, Jānis Cîrulis (1908-1995) later, upon emigrating to the USA, became a famous scientific and medical illustrator. Cirulis remembered that receiving his first Anatomy assignment - illustrating the skull of a primate for the book Mankind in the Making [17] by William Howell thought by himself: 'Now I will have to use the knowledge which Professor Jekabs Primanis imparted to us in his lectures on anatomy [12: 51].' It turned out that this knowledge proved useful for him not only in this assignment, but in all of his following career. Cirrulis' masterpiece was a set of more than 1,000 illustrations for Professor Richard Warren's book Surgery [36] in 1963. This was followed by illustrations for Robert Smith's Anaesthesia for Infants and Children [31] in 1968 and Robert Gross' An Atlas of Children's Surgery [16] in 1970, etc. Later on, already a famous and highly appreciated medical illustrator, Cîrulis gratefully continued to publicly praise the high demands of Primanis at the Academy, saying that he would not be able to accomplish the works without the knowledge he obtained there [1].

In conclusion, it is necessary to note the long-term influence of Primanis on the way Anatomy was taught at the Art Academy, which continued even when it was taught no longer by anatomists, but by artists. The tradition of reproducing anatomy tables initiated by Primmanis and the division between the General and Plastic Anatomy in the Art Academy was preserved in the study programmes of the following Plastic Anatomy lecturers, both sculptors Kārlis Jansons (1896-1986) and Arvīds Drīzulis (1934-2019) up until 2019. Thus, it is possible to say that the scientific approach developed by anatomist and anthropologist Jēkabs Prìmanis has survived through ages and in one way or another it is still present in the Art Academy of Latvia even now.

\section{REFERENCES}

1. Akmentiņš O. (1963). Latviešu mākslinieku panākumi. Latvija Amerikā, 11, 3

2. Amvros'yev, A. P. (2015). Plasticheskaya anatomiya. Vysheishaya shkola. Minsk.

3. Arājs K. (2005). Latviešu kauli. Atmiņas par anatomikumu un antropologijas ziedu laikiem Latvijā. Rīgas Stradiṇa universitāte. Rīga.

4. Archives of Latvian Art Academy. Personnel files. Jēkabs Prīmanis. P - 136. 
5. Archives of Pauls Stradiņš Museum of History of Medicine. Anatomical Drawings (1937-1938) by Baumanis. MVM58409/1-27 and MVM58410/1-12

6. Archives of RSU Anatomy Museum. Lecture notes (1936-1938) in plastic anatomy by Baumanis. AMZ10-15.

7. Audriņš J. (1982) Latvijas mākslas akadēmija. Atmiņu virkne. 1921.-1940. Latvju Māksla, 9, 770-773.

8. Bammes G. (2017) The Complete Guide to Anatomy for Artists \& Illustrators. Search Press Ltd. Tunbridge Wells.

9. Brücke E. W. (1891). Schönheit und Fehler der menschlichen Gestalt. W. Braumueller. Wien.

10. Birze M. (2012). Quid stas, transit hora! Medicīnas apgāds. Rīga.

11. Burāne I. (2000). Jēkabs Prīmanis un Latvijas Mākslas akadēmija. Museum Anatomiae Jacobi Primani - 80. Conference abstract book. Riga.

12. Cīrulis J. (1987). Jānis Cīrulis. His Life and Work. The Art Studio of Janis Cirulis. Boston.

13. Eglītis A. (1932). Latvijas mākslas akadēmiju beigušo diplomdarbi akadēmijas izstādē. Latvijas Kareivis, 293, 4.

14. Grāvere R. (2017). Tā mēs atgriežamies... Ārsts, anatoms un antropologs Jēkabs Prīmanis. Skaldu raksti. Rīga.

15. Grāvere R., Vētra J. (2016). Jēkaba Prīmaņa personības un darbības šķautnes zināmais un mazāk zināmais. Acta medico-historica Rigensia, 10, 90-119.

16. Gross R. E. (1970). Anaesthesia for Infants and Children. W. B. Saunders Co. Philadelphia.

17. Howells W. (1959) Mankind in the Making. Doubleday \& Company. New York.

18. Kačalova T. (1971). Vilhelms Purvìtis. Liesma. Rīga.

19. Koval̦evska M. (1971) Pie skujaina loga. Margaritas Kovaḷevskas sastapšanās ar atmiņām. Laiks, 101, 7.

20. Krukenberg H. (1913). Der Gesichtsausdruck des Menschen. F. Enke. Stuttgart.

21. Langer K. (1884). Anatomie der äusseren Formen des menschlichen Körpers. Toeplitz \& Deuticke. Wien.

22. Lỉbiete I., Grāvere R. (2018). Rīgas Stradiṇa universitātes anatomiskās kolekcijas zudušo vēsturi meklējot. Acta medico-historica Rigensia, 11, 53-91.

23. Linauts L. (1983). Gars un viela. Latvju māksla, 10, 974-975, 998

24. Linauts L. (1984). Gars un viela. Latvju māksla, 11, 1075

25. Mavrodi A., Paraskevas G., Kitsoulis P. (2013). The History and the Art of Anatomy: a source of inspiration even nowadays. Italian Journal of Anatomy and Embriology, 118, 3, 267-276.

26. Neilis K. (1986). Tie trakie gleznotāju gadi. Vaidava.

27. Prīmanis J. (1925). Pāles galvaskausi. Latvijas Universitātes Raksti, 12, 429-480.

28. Purvītis V. (1928). Īss pārskats par Latvijas mākslas akadēmijas darbību. Izglītības ministrijas mēnešraksts, 11, 397-401. 
29. Richer P. (1890). Anatomie artistique : Description des formes extérieures du corps humain au repos et dans les principaux mouvements. E. Plon, Nourrit. Paris.

30. Skulme U. (1937). Igauṇu un lietuvju mākslas izstādes. Daugava, 4, 373-375.

31. Smith R. M. (1968). Anaesthesia for Infants and Children. The C.V. Mosby Co. Saint Louis.

32. Stratz C. H. (1898). Die Schönheit des weiblichen Körpers: den Müttern, Ärzten und Künstlern gewidmet. F. Enke. Stuttgart.

33. Straubs V. (2001). Sava laikmeta liecinieks. Harro von Hirschheydt. Rīga.

34. Sidorova Ye. V. (2015) Rol' anatomicheskikh risunkov v epokhu russkogo klassitsizma. Vestnik Tomskogo gosudarstvennogo universiteta, 398, 84-92.

35. Voskis H. (2005). Topogrāfiskās anatomijas un operatīvās ḳirurgijas kursa un katedras vēsture Latvijas Universitātē. Latvijas Universitātes Raksti. Zinātṇu vēsture un muzejniecība, 684, 63-72.

36. Warren R. (1963). Surgery. W.B. Saunders Co. Philadelphia

\section{Address for correspondence:}

Ieva Libiete

Institute of History of Medicine

Rīga Stradiņš University

Kronvalda Boulevard 9, Rīga, Latvia, LV 1050

E-mail: ieva.libiete@rsu.lv 